\title{
CRUDE GLYCEROL AND WHEY AS CARBON AND NITROGEN SOURCES FOR THE PRODUCTION OF ANTIBIOTICS
}

Slavica llićc ${ }^{*}$, Sandra Konstantinović1, Jovan Ćirić1, Dragiša Savić1, Gordana Gojgić-Cvijović ${ }^{2}$, Vlada Veljković ${ }^{1}$

${ }^{1}$ Faculty of Technology, Leskovac, University of Niš, Serbia

2 ICTM, Department of Chemistry, Belgrade, Serbia

The microorganisam Streptomyces hygroscopicus $\mathrm{CH}-7$ produces antibiotics Hexaene, Nigericine and Elaiophyline. The yield of antibiotics can be increased by changing the fermentation conditions and the composition of the nutrient medium. Based on the previous research with this strain and the literature reviewed, the aim of this work was to study the possibility of using waste materials (whey with proteins in varying ammounts and crude glycerol from the biodiesel production) as a carbon and nitrogen source in order to increase the yeald of antibiotics produced by Streptomyces hygroscopicus $\mathrm{CH}-7$. The maximum concentration of Hexaene $(47,2 \mu \mathrm{g} /$ $\mathrm{cm}^{3}$ ) was achieved in the medium with whey containing $80 \%$ of protein and glycerol from sunflower oil, while the maximum concentration of Elaiophyline $\left(24,3 \mu \mathrm{g} / \mathrm{cm}^{3}\right)$ was achived in the basal medium.
(ORIGINAL SCIENTIFIC PAPER) UDC 615.33:547.426.1:637.344

Keywords: Antibiotics, Streptomyces hygroscopicus, crude glycerol, whey

\section{Introduction}

Bacteria of the genus Streptomyces is one of the most studdied and economically important genera of microorganisams. The reason is the fact that the potencial of Streptomyces in the production of antibiotics and other important biologically active compounds (enzymes, vitamins) remained unsurpassed [1]. The genus Streptomyces belongs to the aerobic Gram-positive bacteria which grow in the form of branched filamentes and form substrate airy mycelium. In a subsequent phase of the life cycle, inside airy mycelium, a typical long chain is formed. The charasteristic of the genus is a high content of guanine $(\mathrm{G})$ and cytosine $(\mathrm{C})$ alkali pairs in DNA (69$78 \%)$ [2].

Streptomyces produce many secondary metabolites such as antibiotics. Active profile of actinomycetes is very wide, which has been demonstrated by the comparison of biological effect between their products. The antibiotic Rifamycin B from the ansamycins group was isolated from the fermentation medium of Amycolatopsis mediterranei culture [3].A macrolide antibiotic Spiramycin was isolated from Streptomyces ambofaciens [4]. Clavulanic acid ( $\beta$-lactam), which indicates a low antibiotic activity and inhibition of penicilase, was isolated from Streptomyces clavuligerus [5]. Anthracycline antibiotics were intensively studied because of their antitumor activity. Ciclamycine, one of the antitumor complex from the anthracycline class, is produced by Streptomyces capoamus [6]. A strain Streptomyces hydroscopcus 111-81 produces polyether complex, Hexaene and Nifimycine [7].

The microbial production of secondary metabolites is very sensitive to the influence of external conditions [8]. For example, the production of many antibiotics depends on the composition of the culture medium in which the microorganism is growing. In recent years, intensive studies in the domain of upgraiding secondary metabolites production and application in biotechnology have been carried out. Therefore, the optimization of the culture medium is a standard procedure in the antibiotics production investigation. The biotech industry is based on the usage of various organisms metabolic activity in order to obtain the compounds that can be applied in other branches of industry. Therefore, the optimization of methods such as the improvement of existing strains and the fermentation conditions are a very important step in the antibiotic production [9]. The fermentation medium should contain all necessary ingredients for the growth and antibiotics biosynthesis of producing microorganism in the most appropriate form, concentration and balance in order to provide the maximal yield. The intensive growth of microorganisms does not ensure the high yield of antibiotics. The composition of the nutrient meduim depends on the type of the microorganism [10]. The optimal medium composition is empiricaly determined with the knowledge of the microorganism regulation. A carbon source has a significant impact on the

\footnotetext{
*Author address: Slavica Ilić, Faculty of Technology,

16000 Leskovac, Bulevar oslobodjenja 124, Serbia

E-mail: ilicslavica@yahoo.com

The manuscript received: November, 06, 2015.

Paper accepted: December, 10, 2015.
} 
secondary metabolism and the production of antibiotics. The increased yield of antibiotics (polyenic, nonpolyenic, polyetheric, Azalomycine B) can be obtained if the fermentation media contain glucose, lactose or glycerol as a carbon source $[11,12]$.

In this paper, the possibility of antibiotics production by cultivating Streptomyces hygroscopicus $\mathrm{CH}-7$ in the medium with glycerol as a carbon source and whey as a nitrogen source was studied. Whey is a major byproduct in dairy industry obtained in the production of cheese or casein, where only $10-20 \%$ of milk is used for the product and other $80-90 \%$ go into the whey. The simplest way to resolve whey is to discharge it into the waterways. Because of environmental consequences (biological pollution caused by the BOD value of 40000 to $60000 \mathrm{ppm}$ ), technological and biotechnological processes of whey utilisation have been explored and developed for a long time. The chemical composition $(70 \%$ of lactose in the dry matter, minerals and vitamins) makes whey to be a very good substrate for the cultivation of microorganisms. Therefore, much attention has to be paid to opportunities for biotechnological utilization in the production of various valuable products (pure edible protein and poly peptides, alcohol, lactic acid, $\beta$-D-galactosidase and vitamins).

Glycerol, as a main byproduct in the chemical reaction of transesterification, represents a significant raw material with the wide use. Crude glycerol (usually $80 \%$ ) is a raw material in the production of pharmaceutical glycerol which can be used in the industry of drugs and cosmetics, tabacco, in the production of resins, urethanes, for the preparation of food and beverage, etc [13]. The process of purification is not often economically justified, and therefore the crude glycerol is a potential raw material for some bioprocesses.

\section{Experimental}

The bacteria Streptomyces hygroscopicus $\mathrm{CH}-7$ is obtained from the microorganisms collection of the Faculty of Chemistry, University of Belgrade. The culture is stored in the refrigerator $\left(+4{ }^{\circ} \mathrm{C}\right)$ on potato glucose agar and, before each series of experiments, activated by repeatedly sifting every four days in the basal medium. The basal medium which is used for monitoring the antibiotics biosynthesis process, has the following composition: $15 \mathrm{~g}$ glucose per litre, $10 \mathrm{~g}$ unfatted soy meal per litre, $3 \mathrm{~g} \mathrm{CaCO}_{3}$ per litre, $3 \mathrm{~g} \mathrm{NaCl}$ per litre. In the basal medium, instead of glucose, a crude glycerol obtained in the biodiesel production from sunflower and rapeseed oil was added as a carbon source in the concentration of $15 \mathrm{~g} / \mathrm{dm}^{3}$. Also, instead of soy meal as a nitrogen source, whey with $80 \%$ and whey with $12 \%$ of protein $\left(10 \mathrm{~g} / \mathrm{dm}^{3}\right)$ were added in the basal medium .

The fermentation was performed in erlenmayers fixed on a rotary shaker with shaking $\left(180 \mathrm{~min}^{-1}, 2 \mathrm{~cm}\right.$ rotation diameter) at the temperature of $28^{\circ} \mathrm{C}$ for a period of $120 \mathrm{~h}$. The experiments were carried out with $200 \mathrm{~cm}^{3}$ substrate in $500 \mathrm{~cm}^{3}$ erlenmayer with a wide neck. For inoculation, the culture 48 hours old was used which was added to the amount of $5 \%$ based on the total volume of the fermentation liquid substrate. Periodically, each $10 \mathrm{~cm}^{3}$ of the fermentation liquid were taken for the analysis.

During the fermentation process, the change in the concentration of produced antibiotics (Hexaene and Elaiophyline) was observed. The antibiotic Hexane was measured spectrophotometrically at $\lambda_{\max }=364 \mathrm{~nm}$ after the extraction with organic solvents. The $0.5 \mathrm{~cm}^{3}$ fermentation broth was extracted with $2.0 \mathrm{~cm}^{3}$ of $\mathrm{n}$-butanol. The concentration was calculated according to the following equation:

$$
\mathrm{C}\left(\mu \mathrm{g} / \mathrm{cm}^{3}\right)=\mathrm{A}_{364} \cdot 66.7
$$

where 66.7 is the experimentally calculated extinction coefficient for Hexaene which is $E_{1 \mathrm{~cm}}^{1 \%}=600$ [14]. The antibiotic Elaiophyline was measured spectrophotometrically at $\lambda_{\max }=252 \mathrm{~nm}$ after the extraction with organic solvents. The $1.0 \mathrm{~cm}^{3}$ fermentation broth was extracted with $2.0 \mathrm{~cm}^{3}$ of n-ethylacetate. The concentration was calculated according to the following equation:

$$
\mathrm{C}\left(\mu \mathrm{g} / \mathrm{cm}^{3}\right)=A_{252} \cdot 25.3
$$

where 25.3 is the experimentally calculated extinction coefficient for Elaiophyline which is $E_{1 c m}^{1 \%}=790$ [15].

\section{Results and Discussion}

The aim of this work was to study the antibiotics production by Streptomyces hygroscopicus $\mathrm{CH}-7$ growing on crude glycerol obtained from the biodiesel production and whey, as a carbon and nitrogen source. The change of the antibiotics concentration was measured. The maximum concentration values of Hexaene and Eliophyline on the nutrient media with different carbon and nitrogen sources are given in Table 1, while the concentration changes of antibiotics during the fermentation process are shown in Figures 1, 2, 3 and 4.

Table 1. Maximum concentration values of antibiotics Hexaene and Elaiophyline during the fermentation by S. hygroscopicus $\mathrm{CH}-7$ in a basal medium with different carbon and nitrogen sources

\begin{tabular}{llcc}
\hline \multicolumn{1}{c}{ Carbon source } & Nitrogen source & $\begin{array}{r}\text { Hexaene } \\
\left(\mu \mathrm{g} / \mathrm{cm}^{3}\right)\end{array}$ & $\begin{array}{c}\text { Elaiophyline } \\
\left(\mu \mathrm{g} / \mathrm{cm}^{3}\right)\end{array}$ \\
\hline Glucose & Soya meal & 36,8 & 24,3 \\
Glycerol from rapeseed oil & Whey (12\% protein) & 18,4 & 14,8 \\
Glycerol from sunflower oil & Whey (80\% protein) & 47,2 & 17,6 \\
\hline
\end{tabular}

During 6 days of the fermentation process monitoring, depending on the source of carbon and nitrogen, bacterium Streptomyces hygroscopicus $\mathrm{CH}-7$ produces different amounts of antibiotics.

The highest concentration of Hexaene was obtained in the culture medium containing whey ( $80 \%$ protein) and the crude glycerol obtained in the biodiesel production from sunflower oil (Table 1). The highest concentration of Elaiophyline was reached in the basal medium with glucose as a carbon source and soy meal as a nitrogen source. 
As the possibility of using the crude glycerol obtained in the biodiesel production from sunflower and rapeseed oil has been already studied $[16,17,18]$, this paper primarily examines the possibility of applying whey with different protein contents, as a source of nitrogen, during the fermentation process using $\mathrm{S}$. hygroscopicus $\mathrm{CH}-7$ in order to obtain antibiotics.

The kinetics of bioprocesses in the basal medium and the medium with whey (12\% protein) and glycerol from rapeseed oil, that is, the change of Hexaene and Elaiophyline concentration are shown in Figures 1 and 2 , respectively. During the fermentation, in the medium with whey (12\% protein) and glycerol from rapeseed oil, the maximum concentration of Hexaene and Elaiophyline are lower than the values in other two substrates (Table 1).

The concentration of Hexaene slightly increases in the first two days of fermentation and reaches the maximum value of $18,4 \mu \mathrm{g} / \mathrm{cm}^{3}$ on the third day (Figure 1), which is twice lower than the value from the basal medium and 2.5 times lower than the medium with whey ( $80 \%$ protein) and glycerol from sunflower oil.

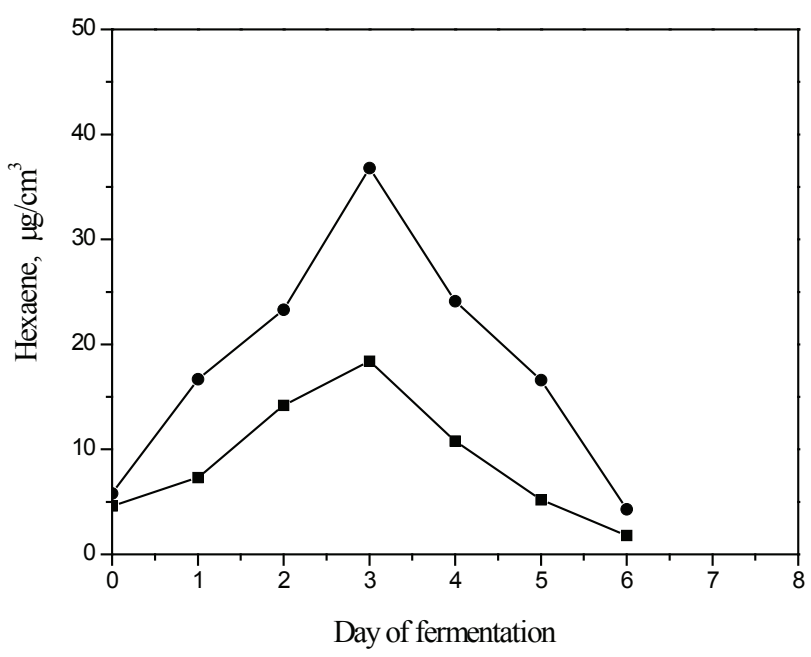

Figure 1. Change in the concentration of Hexaene during the fermentation of $\mathrm{S}$. hygroscopicus $\mathrm{CH}-7$ in the basal medium (---) and the medium with whey (12\% protein) and crude glycerol from rapeseed oil (-口-)

The maximum Elaiophyline concentration was $14,8 \mu \mathrm{g} / \mathrm{cm}^{3}$ and it was reached after four days. The resulting value of the antibiotic is slightly lower than the value realised in the medium with whey ( $80 \%$ protein) and crude glycerol from sunflower oil, as well as $64 \%$ lower than the basal medium (Figure 2).

The results of these studies are consistent with previous studies $[16,17,18]$ of $S$. hygroscopicus $\mathrm{CH}-7$ cultivation on crude glycerol from rapeseed oil. The possibility of using whey with the $80 \%$ and $12 \%$ protein content has not been investigated so far and accordingly the results cannot be compared.

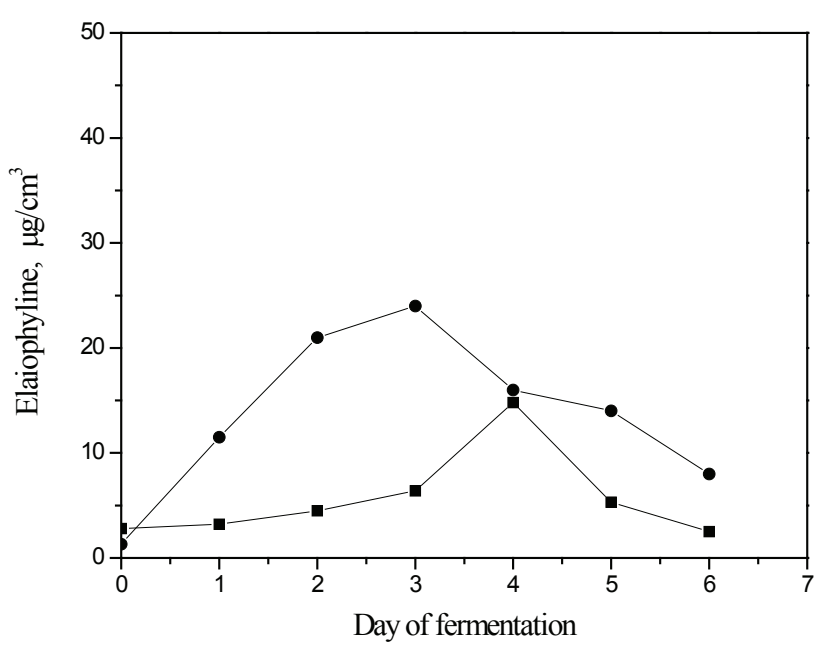

Figure 2. Change in the concentration of Elaiophyline during the fermentation of $S$. hygroscopicus $\mathrm{CH}-7$ in the basal medium (-•-) and the medium with whey (12\% protein) and crude glycerol from rapeseed oil

In the course of the fermentation process of $S$. hygroscopicus $\mathrm{CH}-7$ using the medium containing crude glycerol from sunflower oil as a source of carbon, and whey with $80 \%$ of protein as a nitrogen source, there is the increase of the antibiotic concentration after the very first day (Figure 3). The Hexaene concentration increases and reaches its maximum on the third day, which amounts to $47,2 \mu \mathrm{g} / \mathrm{cm}^{3}$. During the $\mathrm{S}$. hygroscopicus $\mathrm{CH}-7$ growth on the basal medium with soy meal as a nitrogen source, the maximum Hexaene concentration value $\left(36,8 \mu \mathrm{g} / \mathrm{cm}^{3}\right)$ is achieved on in the third day of fermentation, which is a $22 \%$ lower yield compared to the medium with whey ( $80 \%$ protein) and crude glycerol from sunflower oil (Figure 3).

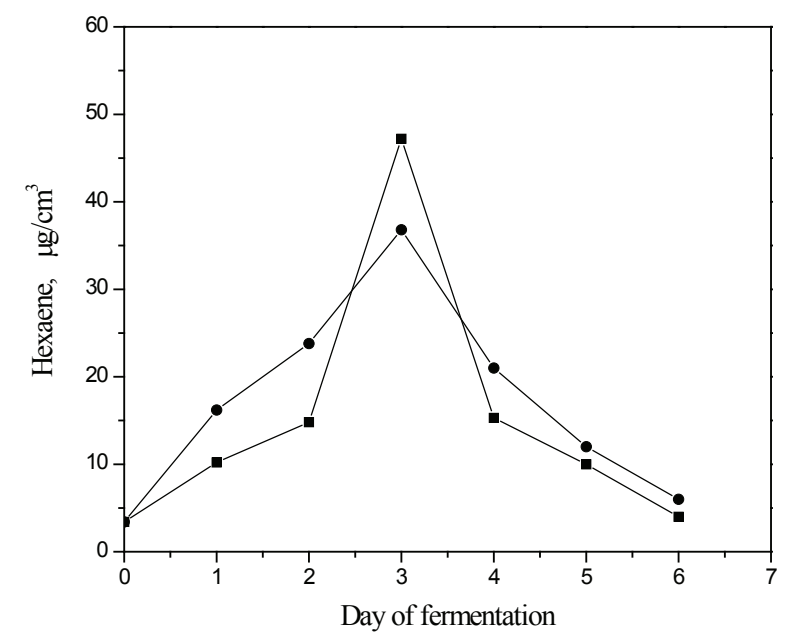

Figure 3. Change in the concentration of Hexaene during the fermentation of $\mathrm{S}$. hygroscopicus $\mathrm{CH}-7$ in the basal medium (---) and the medium with whey ( $80 \%$ protein) and crude glycerol from sunflower oil (-口-) 
The concentration of Elaiophyline increases to $17,6 \mu \mathrm{g} / \mathrm{cm}^{3}$ during during first four days and then decreases. In the basal medium, with soy meal as a nitrogen source, the maximum Elaiophyline concentration was $24,3 \mu \mathrm{g} / \mathrm{cm}^{3}$, which is $28 \%$ higher than the maximum value obtained on the media with whey and crude glycerol (Figure 4).

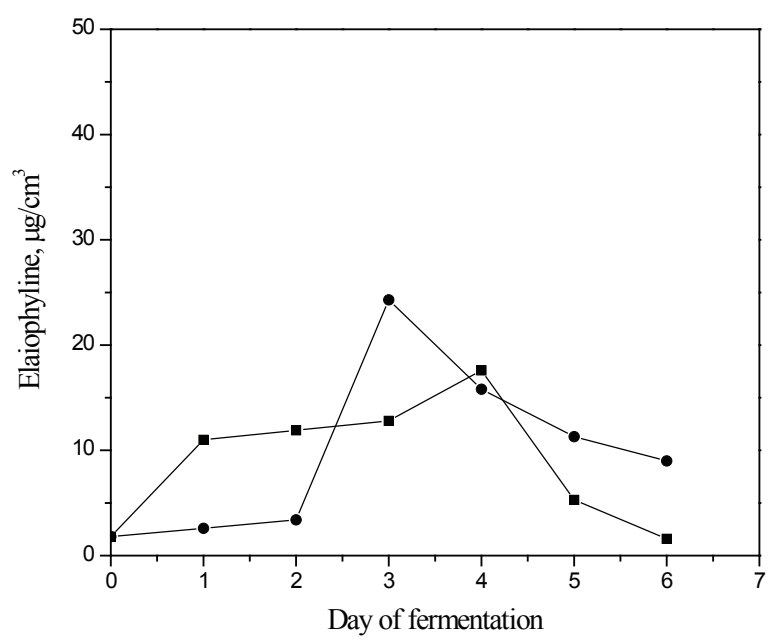

Figure 4. Change in the concentration of Elaiophyline during the fermentation of $\mathrm{S}$. hygroscopicus $\mathrm{CH}-7$ in the basal medium (-•-) and the medium with whey (80\% protein) and crude glycerol from sunflower oil (-m-)

\section{Conclusion}

Based on the results obtained in this research, it can be concluded that secondary raw materials can be used as carbon and nitrogen sources. The maximum concentration of Hexaene was obtained in the medium with whey containing $80 \%$ protein and crude glycerol from sunflower oil and it amounts to $47,2 \mu \mathrm{g} / \mathrm{cm}^{3}$, which is a $22 \%$ higher yield compared to the basal medium. In contrast to Hexaene $\mathrm{H}-85$, S. hygroscopicus $\mathrm{CH}-7$ shows the best production of Elaiophyline in the medium with soy meal $\left(24,3 \mu \mathrm{g} / \mathrm{cm}^{3}\right)$. The smallest concentration of both antibiotics was obtained in the medium containing crude glycerol from rapeseed oil and whey with $12 \%$ protein.

\section{Acknowledgments}

This work has been funded by the Ministry of Education, Science and Technological Development of the Republic of Serbia (Project III 45001).

\section{References}

[1] H.M.Atta, S.M. Dabour, S.K. Desoukey, Sparsomycin Antibiotic Production by Streptomyces Sp. AZ-NIOFD1: Taxonomy, Fermentation, Purification and Biological Activities, American-Eurasian Journal of Agricultural and Environmental Scienc, 5 (2009) 368-377.

[2] D.A. Hoopwood, Streptomyces genetics in pure and applied research, in Genetics and molecular biology of industrial microorganisms, C. L. Hersberger, S. W. Queener, G. Hegeman Ed., American Society for Microbiology, Washington 1989, p. 12.

[3] O.M. El-Tayeb, A. A. Salama, M. M. Hussein, H.F. ElSedawai, Optimization of industrial production of rifamycin B by Amycolatopsys mediterranei. I. The role of colony morphology and nitrogen sources in productivity, African Journal of Biotechnology, 3 (5) (2004) 266-272.

[4] J.Zhihua, C.Pelin, Improved production of spiramycin by mutant Streptomyces ambofaciens, Journal of Zhejiang University SCIENCE, 5 (6) (2004) 689-695.

[5] J. Birnbaum, F. M. Kahan, H. Kropp, J. S. Mac Donald, Carbapenems, a new class of beta-lactam antibiotics. Discovery and development of imipenem/ cilastatin, The American Journal of Medicine Supplements, 6A (78) (1985) 3-21.

[6] S.C.Martins, A.M. Souto-Maior, Anthracycline production by Streptomyces capoamus in batch fermentation, Brazilian Archives of Biology And Technology, 46 (2003) 483-488.

[7] V. Gesheva, V. Ivanova, R. Gesheva, Effects of nutrients on the production of AK-111-811 macrolide antibiotic by Streptomyces hygroscopicus, Microbiological Research, 160 (2005) 243-248.

[8] A.W. Bunch, R.E. Harris, The manipulation of microorganisms for the production of secondary metabolite, Biotechnology and Genetic Engineering Reviews, 4 (1986) 117-44.

[9] S. Parekh, V.A. Vinci, R.J. Strobel, Improvement of microbial strains and fermentation processes, Applied Microbiology and Biotechnology, 54 (3) (2000) 287-301

[10] A. Pereda, K.G. Summers, D.L.Stassi, X. Ruan, L.Katz, The loading domain of the erythromycin polyketide synthase is not essential for erythromycin biosynthesis in Saccharopolyspora erytraea, Microbiology, 144 (1998) 543-553.

[11] V. Colombie, C. Bideaux, G. Goma, L.J. Uribelarrea, Effects of glucose limitation on biomass and spiramycin production by Streptomyces ambofaciens, Bioprocess and Biosystems Engineering, 28 (2005) 55-61.

[12] E. Jonsbu, M.Mcintyre, J. Nielsen, The influence of carbon sources and morphology on nystatin production by Streptomyces noursei, Journal of Biotechnology, 95 (2002) 133-144.

[13] T.Willke, K. Vorlop, Biotransformation of glycerol into 1,3-propanediol, European Journal of Lipid Science and Technology, 110 (9) (2008) 831e40.

[14] I.Karadžić, G.Gojgić-Cvijović, J.Vučetić, Hexaene H-85. A Hexaene macrolide complex, The Journal of Antibiotics, 44 (1991) 1452-5.

[15] M.Arai, Azalomycins B ana F. Two new antibiotics, Journal of Antibiotics,Ser A, 13

[16] J. Ćirić, S. Ilić, S. Konstantinović, V. Veljković, G. GojgićCvijović, D. Savić, Fermentacija glicerola pomoću bakterije Streptomyces hygroscopicus $\mathrm{CH}^{-7}$, Advanced technologies, 2 (1) (2012), 20-25.

[17] J.Vučković, Kinetika fermentacije bakterije Streptomyces hygroscopicus $\mathrm{CH}^{-7}$ na podlozi sa glicerolom, Diplomski rad, Leskovac 2012.

[18] S.llić, S.Konstantinović, G.Gojgic-Cvijović, D.Savić, V.Veljković, The impact of glycerol and some carbohydrates on antibiotic production by Streptomyces hygroscopicus $\mathrm{CH}$ 7, Medicinal Chemistry Research, 22 (2) (2013), 934-937. 


\section{SIROVI GLICEROL I SURUTKA KAO IZVORI UGLJENIKA I AZOTA ZA PRODUKCIJU ANTIBIOTIKA}

Slavica llić ${ }^{1}$, Sandra Konstantinović ${ }^{2}$, Jovan Ćirić ${ }^{1}$, Dragiša Savić ${ }^{1}$, Gordana Gojgić-Cvijović ${ }^{\text {, Vlada Veljković }}{ }^{1}$

${ }^{1}$ Tehnološki fakultet, Leskovac,Univerzitet u Nišu, Srbija

2 IHTM, Beograd, Srbija

Mikroorganizam Streptomyces hygroscopicus $\mathrm{CH}-7$ produkuje antibiotike Heksaen, Nigericin i Elaiofilin. Promenom uslova fermentacije i sastava hranljive podloge može se povećati produkcija antibiotika. Na osnovu dosadašnjih istraživanja sa ovim sojem i literaturnog pregleda, cilj ovog rada je bio da se ispita mogućnost primene otpadnih sirovina (surutke sa različitim procentom proteina i sirovog glicerola iz proizvodnje biodizela) kao izvora ugljenika i azota, kako bi se povećala produkcija antibiotika pomoću Streptomyces hygroscopicus $\mathrm{CH}-7$. Maksimalna koncentracija Heksaena $\left(47,2 \mu \mathrm{g} / \mathrm{cm}^{3}\right)$ postignuta je na podlozi sa surutkom (koja sadrži $80 \%$ proteina) i glicerolom iz suncokretovog ulja, dok je maksimalna koncentracija Elaiofilina $\left(24,3 \mu \mathrm{g} / \mathrm{cm}^{3}\right)$ ostvarena na osnovnoj podlozi.
Ključne reči: antibiotici, Streptomyces hygroscopicus, sirovi glicerol, surutka 